\title{
The Innovation and Application of Internet Finance in the Era of Big Data
}

\author{
An Empirical Study on Consumption and Internet Finance
}

\author{
Xiaoman Guo \\ School of Economics \\ Sichuan University \\ Chengdu, China
}

\begin{abstract}
The technology of big data and cloud computing develops so rapidly, which has brought new opportunities to Internet finance. China has caught up with the trend of big data popularization, innovates actively. And the main kinds of business models include the third party payment, peer to peer lending, crowdfunding and big data credit. However, how the Internet finance influences the Chinese economy is still under research. This study analyzes the relationship between Internet finance and people's consumption in China with the method of co-integration test and Granger causality test.
\end{abstract}

Keywords-Internet finance; consumption; disposable income

\section{INTRODUCTION}

In recent years, the development of China's internet financial industry has been manifesting its distinctive features: the rapidity of its growth and the giant size of its volume. Take Peer-to-peer lending, a core section of the internet financial industry as an example. The number of peer-to-peer lending companies in China has rocketed up from 40 in 2012 to 6619 in May 2019, over 165 times its original size. Furthermore, the transaction volume of China's third party mobile payment market in 2018 had reached 170.75 trillion RMB, accounted for nearly two times of China's total GDP of 90.03 trillion. It is self-evident that China's internet financial industry has developed to a relatively large scale.

Franklin Allen (2005), in his paper concluded that China's economy has been growing at a very fast rate, but its financial systems as well as institutions are all underdeveloped. And it is undeniable that the starts China's internet system as well as financial industry was much delayed than the developing countries. The internet financial industry, however, as a creative financial channel, started almost at the same time both home and abroad. Hence there is much space to communicate between the domestic market and the international market, especially in an era of big data when internet innovation and application is never more active. McKinsey Global Institute (2011) thought the business and economic possibilities of big data and its wider implications are important issues that business leaders and policy makers must tackle. The theory is also applicable in
China by employing the big data technique to make innovation in the modes of internet financial industry and meanwhile to improve and perfect the existing system. The first person to have brought up the concept of internet financing to China is Xie Ping (2012), who categorized the internet banking and e-commerce into the internettransformation of the traditional financial institutes. He also analyzed the modes of third-party payment, internet currency, peer-to-peer lending, big data crediting, internet loaning, crowdfunding and etc. Xie also thought that internet financing, through improving the efficiency of resource allocation plus reducing the costs of transaction, will produce enormous social and economic benefits. Ma Yun (2013) believed the innovation of internet financing will contribute a long-lasting effect to China's economic growth. Li Qi (2015), after going through a lot of references, concluded that the third-party payment and internet loaning will be the core in the internet financial industry. Zheng Zhilai (2018), from the perspective of capital supplier and capital demander, studied the influence of internet financing on the SME financing under the background of big data. To speak generally, economists and scholars have agreed on the theory that internet financing can promote economic growth and they together studied its development and theory system and its influence mechanism on the macroeconomics under big data. However, empirical researches on the influence of internet financing on economic growth is rarely carried out. China's economy is transforming from its falling trend to a newnormal one which focuses on expanding the domestic demand and upgrading the industrial structure by consumption. Therefore, exploring the impact of internet financing on Chinese citizens' consumption has a profound practical significance.

\section{THE LOGIC THEORY}

In the era of big data, the influence of Internet finance on Chinese people consumer spending is mainly reflected in the following aspects. Firstly, Internet finance could improve the convenience and success of consumption. As mentioned above, the third party payment is one of the very important modes of Internet finance, forming a relatively large scale, which could be illustrated by the example of Alipay. Alibaba Group's Alipay, as the largest third party payment platform 
in china, has over 1000 million registered users, becoming the largest in the world. Even if the user does not carry cash or cards in the actual payment scenarios, they can directly use the third party mobile payment to finish the payment without hesitation. Internet finance breaks the restrictions of region and space when people consuming, greatly improving the convenience and success rate.

Secondly, Internet finance has the ability to advance resources allocation. The appearance and explosive growth of various internet financial products, including internet monetary fund, peer-to-peer lending and crowd funding, has vastly enriched Chinese people's investment choice, mining a large demand for financial management among the potential target customers. Take the Alibaba Group's Yu'E Bao as an example, which collaborates with Tianhong Fund, attracting customers to use with high yield rate. By January 2019, Yu'E Bao serving 600 million users, has brought revenue over 100 billion yuan for the users, which will affect the user's consumption. Besides, there are a lot of other internet financial tools, and they work together to facilitate the asset allocation and consumption averaging among one's lifetime, which will lead to higher level of consumption.

The third aspect is the development and popularization of internet financial consumer credit, which is also very significant and promising, using big data credit to classify the consumers and give them a certain amount of consumer credit. Similarly, take the Alibaba Group's Zhima Credit and Ant check later for examples. Zhima Credit based on assessment of tremendous information, could easily apply to various cases, such as credit cards, consumer finance and financial lease. This is one of the most direct manifestations of big data technology influencing the Internet finance. Meanwhile, Ant check later cooperates with Zhima Credit, offering small Internet consumer credit to consumers. Consumers demand could be satisfied whenever, which increases the level of consumer utility, and promotes consumption.

The theories above illustrate how Internet finance affects consumption expenditures. Next, empirical analysis will be carried out to verify whether the perspective is correct.

\section{DATA DESCRIPTION AND SOURCES}

In order to study the relationship between Internet finance and consumption, according to the absolute income hypothesis of Keynes, it is obvious to establish an econometric model, with income and Internet finance as explanatory variables, consumption as explanatory variable. As for data selection, income, consumption and the Internet finance are represented by per capita disposable income of urban residents in China (INC), per capita consumption of urban residents in China $(\mathrm{CON})$ and third party online payment transaction scale (TPP) respectively. As the third party payment account for a very large and significant part of the current Internet finance, while it's development scale change is almost the same with Internet finance, it is reasonable to choose this variable to represent. As for time selection, quarterly data are taken to expand the sample capacity. According to the availability, data from 2008 the first quarter to 2018 the fourth quarter is adopted as sample. All the data is from the National Bureau of Statistics of China and iResearch.

\section{EMPIRICAL ANALYSIS}

\section{A. Unit Root Test}

This involves testing for the stationarity of the individual variables using the Augmented Dickey-Fuller (ADF) test to find the existence of unit root in each of the time series. The results of the ADF test are reported in Tables below:

TABLE I. ADF STATIONARITY TEST AT LEVELS AND FIRST DIFFERENCE

\begin{tabular}{|c|l|l|l|l|l|}
\hline Variable & Type $(\mathbf{C}, \mathbf{T}, \mathbf{K})$ & ADF Test Statistic & $\mathbf{5 \%}$ Level & $\mathbf{1 0 \%}$ Level & \multicolumn{1}{|c|}{ Result } \\
\hline $\boldsymbol{C O N}$ & $(\mathrm{C}, \mathrm{T}, 4)$ & -2.811914 & -3.574244 & -3.221728 & non-stationary \\
\hline $\boldsymbol{I N C}$ & $(\mathrm{C}, \mathrm{T}, 3)$ & -2.893912 & -3.568379 & -3.218382 & non-stationary \\
\hline $\boldsymbol{T P P}$ & $(\mathrm{C}, \mathrm{T}, 0)$ & 2.442095 & -3.552973 & -3.209642 & non-stationary \\
\hline$\Delta \boldsymbol{C O N}$ & $(\mathrm{C}, 0,3)$ & -2.966526 & -2.967767 & -2.622989 & stationary \\
\hline$\Delta \boldsymbol{I N C}$ & $(\mathrm{C}, \mathrm{T}, 3)$ & -4.036091 & -3.587527 & -3.229230 & stationary \\
\hline$\Delta \boldsymbol{T P P}$ & $(\mathrm{C}, \mathrm{T}, 0)$ & -4.131523 & -3.557759 & -3.212361 & stationary \\
\hline
\end{tabular}

a. " $\triangle$ "represents variables at first difference.

${ }^{\text {b. }} \mathrm{C}, \mathrm{T}$ in type represent including intercept and trend, respectively. $\mathrm{K}$ represents the lag length

c. The best lag length is determined by Akaike information criterion (AIC) and Schwarz Criterion (SC)

d. Author's Estimation using Eviews 8.0

The "Table I" above has shown that all the variables were not stationary in levels, but all the variables were stationary at first difference. On the basis of this, the null hypothesis of non-stationary is rejected and it is safe to conclude that the variables are stationary. This implies that the variables are integrated of order one, and there might be long-run equilibrium relationship between these variables. Cointegration test could be done for further analysis.

\section{B. Co-integration Test}

The result of the co-integration condition (that is the existence of a long term linear relation) is presented in "Table II" below using methodology proposed by Johansen (1998) and Juselius (1990), which is usually called JJ test. 
TABLE II. RESUlt OF JOHANSEN Co-INTEGRATION TEST

\begin{tabular}{|c|c|c|c|c|}
\hline $\begin{array}{c}\text { Hypothesized No. } \\
\text { of CE(s) }\end{array}$ & Eigenvalue & $\begin{array}{c}\text { Trace } \\
\text { Statistic }\end{array}$ & $\begin{array}{c}\mathbf{5 \%} \\
\text { Critical } \\
\text { Value }\end{array}$ & Prob.** \\
\hline None $*$ & 0.762458 & 60.82731 & 29.79707 & 0.0000 \\
\hline At most 1 & 0.360720 & 14.83016 & 15.49471 & 0.0628 \\
\hline At most 2 & 0.015901 & 0.512935 & 3.841466 & 0.0628 \\
\hline
\end{tabular}

The trace statistics in the co-integration table indicate that there is a cointegration relation when significance level is $5 \%$. Then the cointegration test of Engle and Granger (EG test) could be done to indicate the long term linear relation. Firstly, it is needed to use ordinary least squares model (OLS) to estimate the variables. The cointegration regression equation is shown as below.

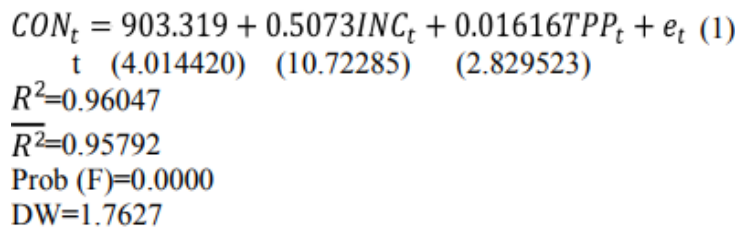

The second step of EG test is using Augmented DickeyFuller test to know whether the residual sequence is stationary. The result is shown as follow.

TABLE III. ADF TEST FOR RESIDUAL SEQUENCE

\begin{tabular}{|l|c|c|c|c|c|}
\hline Residual & $\begin{array}{c}\text { ADF test } \\
\text { statistic }\end{array}$ & $\mathbf{5 \%}$ Level & $\mathbf{1 0 \%}$ Level & Prob.* & Result \\
\hline$\theta_{t}$ & -1.798724 & -1.953858 & -1.609571 & 0.0690 & stationary \\
\hline
\end{tabular}

It is revealed from "Table III" that the residual sequence is stationary that is to say; the cointegration equation makes sense with high fitting degree. Furthermore, t value suggests that the effect of variables is significant. The economic meaning of this equation is when disposable income of urban households increase 1 yuan, consumption expenditures of urban households will increase 0.5073 yuan. When the thirdparty online payment transaction increases 10 million yuan, consumption expenditures of urban households will increase 0.1616 yuan.

\section{Error Correction Model}

The main form of error correction model (ECM) is advanced by Davidson, Hendry, Srba and Yeo in 1978, which is also called DHSY model. This theory intends to combine variables at levels and at first difference together, in order to reflect both the long term relationship and short term relationship between variables. The estimation of ECM is as below.
$\Delta C O N_{t}=-28.9146+0.4933 \Delta I N C_{t}+0.04327 \Delta T P P_{t}-0.9081 e c m_{t-1}$ (2)

$$
\begin{aligned}
& \mathrm{t} \quad(-0.6409) \\
& R^{2}=0.96047 \\
& \overline{R^{2}}=0.95792 \\
& \operatorname{Prob}(\mathrm{F})=0.0000 \\
& \mathrm{DW}=1.7627
\end{aligned}
$$

It is clear to see that the effect of "ECM" is significant, and the negative coefficient implies that the adjustment degree of their relation from short-term deviation to long-term balance is big. Based on the research above, third-party payment transaction has positive influence on consumption expenditures. Granger causality test could be done to further verify the hypothesis.

\section{Granger Causality Test}

The lag length is 2, determined by Akaike information criterion (AIC) and Schwarz Criterion (SC). Granger Causality Test between CON and TPP (as shown in "Table IV"):

TABLE IV. ADF TEST FOR RESIDUAL SEQUENCE

\begin{tabular}{|c|l|c|}
\hline Null Hypothesis: & \multicolumn{1}{|c|}{ F-Statistic } & Prob. \\
\hline TPP does not Granger Cause CON & 3.39088 & 0.0486 \\
\hline CON does not Granger Cause TPP & 0.77235 & 0.4719 \\
\hline
\end{tabular}

According to the results obtained from the Granger causality test, when significance level is 5\%, third-party payment transaction Granger Cause consumption expenditures, on the other hand, consumption expenditures does not Granger Cause third-party payment transaction. This result also supports the study before.

\section{CONCLUSION}

How the Internet finance influence people's consumption has been analyzed theoretically from different aspects in this paper. Next, empirical research, including cointegration test, EG test, error correction model and Granger causality test 
has been used to detect the relationship between Internet finance and consumption expenditures. The finding shows that development of Internet finance can promote China's consumer spending, expanding domestic demand. In the era of big data, on the base of ensuring consumer's safety, Chinese government needs to develop the Internet finance industry actively, steady and healthy, to make it better serving Chinese economic development.

\section{REFERENCES}

[1] Allen F, Qian J, Qian M. "Law, finance, and economic growth in China" [J]. Journal of financial economics. 2005, 77, 57-116.

[2] James Manyika, Michael Chui. Big data: The next frontier for innovation, competition, and productivity [R]. The Internet finance modes research, McKinsey Global Institute. 2011, 5 .

[3] Li Qi. Theoretical and empi rical analysis of credit and risk in Internet finance, Chongqing University [D]. 2015.

[4] Ma Yun. Financial industry needs disrupter [J]. Entrepreneur blog. 2013, 7, 11-11.

[5] Xie Ping, Zou Chuanwei. The Internet finance modes research [J]. Journal of Financial Research. 2012, 12, 11-14.

[6] Zheng Zhilai. The impact of Internet finance on the SMEs financing under the background of big data [J]. Internet finance. 2018, 11, 6366 